\title{
SIDT2 is involved in the
}

\section{NAADP-mediated release of calcium from insulin secretory granules}

\author{
Guoying Chang', Rui Yang1, Yanan $\mathrm{Cao}^{2}$, Aifang Nie², Xuefan Gu1 and Huiwen Zhang'
}

1Department of Pediatric Endocrinology and Genetic Metabolism, Xinhua Hospital, Shanghai Institute for Pediatric Research, Shanghai Jiao Tong University School of Medicine, Shanghai, China 2Shanghai Clinical Center for Endocrine and Metabolic Diseases, Shanghai Key Laboratory for Endocrine Tumors, Rui-Jin Hospital, Shanghai Jiao Tong University School of Medicine, Shanghai, China

Correspondence should be addressed to $\mathrm{H}$ Zhang or X Gu Email

huiwenzhang@yahoo.com or gu_xuefan@163.com

\begin{abstract}
The Sidt2 global knockout mouse (Sidt2-l-) has impaired insulin secretion. The aim of this study was to assess the role of SIDT2 protein in glucose-induced insulin secretion in primary cultured mouse $\beta$-cells. The major metabolic and electrophysiological steps of glucose-induced insulin secretion of primary cultured $\beta$-cells from Sidt2-l- mice were investigated. The $\beta$-cells from Sidt2-l- mice had normal $N A D(P) H$ responses and $K_{\text {ATP }}$ and $\mathrm{K}_{\mathrm{V}}$ currents. However, they exhibited a lower $\left[\mathrm{Ca}^{2+}\right]_{i}$ peak height when stimulated with $20 \mathrm{mM}$ glucose compared with those from WT mice. Furthermore, it took a longer time for the $\left[\mathrm{Ca}^{2+}\right]_{i}$ of $\beta$-cell from Sidt2-l- mice to reach the peak. Pretreatment with ryanodine or 2-aminoethoxydiphenyl borate (2-APB) did not change $\left[\mathrm{Ca}^{2+}\right]_{i}$ the response pattern to glucose in Sidt2-/- cells. Extraordinarily, pretreatment with bafilomycin A1(Baf-A1) led to a comparable $\left[\mathrm{Ca}^{2+}\right]_{i}$ increase pattern between these two groups, suggesting that calcium traffic from the intracellular acidic compartment is defective in Sidt2-l- $\beta$-cells. Bathmediated application of $50 \mathrm{nM}$ nicotinic acid adenine dinucleotide phosphate (NAADP) normalized the $\left[\mathrm{Ca}^{2+}\right]_{\mathrm{i}}$ response of Sidt2-l- $\beta$-cells. Finally, glucose-induced CD38 expression increased to a comparable level between Sidt2-/- and WT islets, suggesting that Sidt2-/islets generated NAADP normally. We conclude that Sidt2 is involved in NAADP-mediated release of calcium from insulin secretory granules and thus regulates insulin secretion.
\end{abstract}

\section{Introduction}

Lysosomal proteomic analyses suggest that, in addition to the well-known lysosomal membrane proteins, e.g. LAMP1, LAMP2, some less-abundant proteins without clear physiological function reside on lysosomal membranes, including SIDT2 (Bagshaw et al. 2005, Chapel et al. 2013, Zhang et al. 2007). As a member of the SID1 transmembrane family (Elhassan et al. 2012), SIDT2 was presumed to be a small RNA membrane transporter. However its exact function has not been explored experimentally.

Currently, no known human diseases are caused by SIDT2 gene mutations. To explore its pathophysiological function, we generated a global knockout Sidt2-/- mouse model, which exhibited age-dependent increased plasma glucose levels and impaired glucose tolerance (Gao et al.

Published by Bioscientifica Ltd 
2013). Islets from Sidt2-/- mice cultured in vitro produced less insulin when stimulated with a high concentration of glucose or a depolarizing concentration of $\mathrm{KCl}$.

Under physiological conditions, glucose-induced insulin release depends on rapid glucose uptake and metabolism in the pancreatic $\beta$-cells, which results in increased cytosolic ATP/ADP, sequential closure of ATP-sensitive potassium channels $\left(\mathrm{K}_{\mathrm{ATP}}\right)$ and depolarization of the cell membrane (Bratanova-Tochkova et al. 2002, Eliasson, et al. 1997, Gylfe et al. 2000). Such depolarization activates membrane voltage-gated $\mathrm{Ca}^{2+}$ channels and allows extracellular $\mathrm{Ca}^{2+}$ to enter the cytoplasm, which in turn induces $\mathrm{Ca}^{2+}$ release from intracellular stores. The resulting rise in $\left[\mathrm{Ca}^{2+}\right]_{\mathrm{i}}$ then triggers insulin secretory granule (ISG) exocytosis. Abnormalities in intracellular $\mathrm{Ca}^{2+}$ signals have been associated with impaired insulin secretion in both rodent and human pancreatic $\beta$-cells (Islam 2010).

$\mathrm{Ca}^{2+}$-induced $\mathrm{Ca}^{2+}$ release (CICR) from intracellular stores is a critical step during insulin secretion in both INS cell line and mouse pancreatic $\beta$-cells (Kang et al. 2005, Kang and Holz 2003, Roderick et al. 2003, Varadi and Rutter 2004). Acidic organelles such as lysosomes and ISGs are the physiological sources of intracellular free $\mathrm{Ca}^{2+}($ Christensen et al. 2002, Suckale and Solimena 2010), which are mobilized in response to the second messenger nicotinic acid adenine dinucleotide phosphate (NAADP) (Galione et al. 2009, Kinnear et al. 2004, Yamasaki et al. 2004). Local $\mathrm{Ca}^{2+}$ release from the acidic stores is then amplified by $\mathrm{ER} \mathrm{Ca}^{2+}$ release via a CICR-dependent manner (Patel et al. 2001). However, the NAADP receptor remains elusive (Calcraft et al. 2009, Morgan and Galione 2014, Wang et al. 2012). Two-pore channels (TPCs) were proposed as the long sought-after NAADP receptor in the intracellular acidic compartment (Calcraft et al. 2009, Ruas et al. 2015). However, study by other groups has suggested that TPCs are NAADP-independent highly selective $\mathrm{Na}^{+}$channels (Cang et al. 2013, Wang et al. 2012). More study on this pathway is imperative.

The aim of this study was to investigate the role of SIDT2 during glucose-induced insulin secretion. We show that SIDT2 is localized in ISGs, where it participates in NAADP-mediated ISG calcium release, playing a critical role in regulating glucose homeostasis.

\section{Materials and methods}

\section{Animals}

Generation of the Sidt2-/- mice was described previously (Gao et al. 2013). All mice were housed in Animal Laboratory Center at Xinhua hospital, Shanghai, China. The Institutional Review Ethics Board of Xinhua Hospital approved all procedures involving mice. Male mice aged 6 months age were used in this study.

\section{Islet isolation and primary cell culture}

The islets were isolated as described previously (Lacy and Kostianovsky 1967). Briefly, islets were incubated in $0.05 \mathrm{mg} / \mathrm{ml}$ trypsin without phenol red for $3 \mathrm{~min}$ at $37^{\circ} \mathrm{C}$. The cells were then centrifuged, and re-suspended in RPMI 1640 supplemented with 10\% fetal calf serum (Gibco), $100 \mathrm{U} / \mathrm{ml}$ penicillin, and $0.1 \mathrm{mg} / \mathrm{ml}$ streptomycin. Single cells were then spread onto coverslips pre-treated with poly-L-lysine (15-30 kDa; Sigma). The cells began to form monolayers after $48 \mathrm{~h}$ of culture.

\section{Sidt2 RNA analysis}

Total RNA was extracted from the pancreatic islets. The forward and reverse primers of pair 1 were located within exons 17 and 18, respectively. Qualitative realtime RT-PCR (qPCR) using pair 1 was performed to analyze the residual RNA content. The forward and reverse primers of pair 2 were designed against regions in exons 2 and 5, respectively, whereas those of pair 3 were in exons 1 and 6 . To confirm the deletion of exon 2 of Sidt2 gene at the mRNA level, RT-PCR was performed using primer pairs 2 and 3. Amplicons from primer pair 3 were directly sequenced. The sequences of three primer pairs were shown in Table 1 .

\section{Western blotting analysis}

A total of about 200 isolated islets were lysed in $100 \mu \mathrm{l}$ $1 \times$ RIPA buffer supplemented with protease inhibitors

Table 1 Oligonucleotide primers used to amplify Sidt2 cDNA

\begin{tabular}{lll} 
Primers & & \multicolumn{1}{c}{ Forward primer } \\
\cline { 1 - 1 } Primer1 & & CTTCAACAACATCCTCAGCAAC \\
Primer2 & & GTGAATGTCCTGAACAAGCAGA \\
Primer3 & & AGCGAGCTGGTCAACATCTAC \\
\hline
\end{tabular}

\begin{tabular}{lll}
\multicolumn{1}{c}{ Reverse primer } & & Length \\
\hline ATGGCGTAAAACAGACCAAAGT & & $161 \mathrm{bp}$ \\
CTTGACAATTACCGAGTCCACA & & $360 \mathrm{bp}$ \\
GGTACATGCCAATGAAGGCTA & & $535 \mathrm{bp}$ \\
\hline
\end{tabular}


(Beyotime, Shanghai, China). Total proteins were extracted and separated using a 10\% SDS-PAGE gel followed by wet transfer onto PVDFs. The primary antibodies used were goat polyclonal anti-SIDT2 (1:300 dilution; Santa-Cruz Biotechnology), rabbit anti-CD38 (1:500 dilution; Novus Biologicals, Littleton, CO, USA), and mouse monoclonal anti-tubulin (1:1000 dilution; Beyotime). Signals were detected using HRP-conjugated secondary antibodies and ECL Detection Kit (Beyotime).

\section{Immunofluorescence staining on pancreas sections and isolated primary $\beta$-cells}

Five-micrometer paraffin-embedded pancreas sections were stained as described previously (Gao et al. 2013). Isolated primary $\beta$-cells were fixed with $4 \%$ paraformaldehyde for $20 \mathrm{~min}$, permeabilized for $20 \mathrm{~min}$ in $0.2 \%$ Triton X-100 buffer, blocked with PBS containing $5 \%$ BSA, and subjected to double immunofluorescence staining. They were first incubated with anti-SIDT2 (1:200) and anti-insulin antibodies (1:100 dilution, Cell Signaling Technology). Then they were incubated with Alexa Fluor 488 donkey-anti-rabbit IgG and Alexa Fluor 594 chicken-anti-goat IgG (1:200 dilution, Molecular Probes). Images were visualized by confocal microscopy (Leica 710, Mannheim, Germany). The co-localization of SIDT2 with insulin was analyzed by Image Pro Plus 6.0 and expressed as Pearson's correlation coefficient, where $P$ values $>0.5$ indicated a significant correlation.

\section{Assessment of $\mathrm{NAD}(\mathrm{P}) \mathrm{H}$ using a fluorimetric assay and an enzymatic recycling method}

Suspension of dispersed islet cells $\left(10^{6}\right.$ cells $\left./ \mathrm{ml}\right)$ was in 96-well plates in a temperature controlled chamber in Krebs-Ringer Bicarbonate Buffer (KRBB) supplemented with $3 \mathrm{mM}$ glucose. NAD(P)H fluorescence $(340 \mathrm{~nm}$ excitation, $420 \mathrm{~nm}$ emission) was measured using a Hitachi F-2000 fluorescence spectrophotometer. The fluorescence intensity was represented as arbitrary units (AU).

Batches of 100 islets were incubated in $20 \mathrm{mM}$ glucose for $10 \mathrm{~min}$, and then extracted using RIPA buffer. The aliquots were heated at $60^{\circ} \mathrm{C}$ for $10 \mathrm{~min}$ to eliminate both NAD and NADP. NADPH levels were then determined by the enzymatic recycling method using $\mathrm{NAD}(\mathrm{P}) \mathrm{H}$ Assay Kit (AAT Bioquest, Sunnyvale, CA, USA). The mean changes in NADPH were expressed as a percentage of unstimulated batches.

\section{Electrophysiological measurements of $\mathrm{K}_{\text {ATP }}$ and $\mathrm{K}_{\mathrm{V}}$ currents in single islet $\beta$-cells}

Whole-cell patch-clamp recordings in dispersed $\beta$-cells were conducted using a patch-clamp amplifier EPC10 (HEKA Electronik, Lambrecht, Germany) as reported previously with some modification (Deng et al. 2014). The $\beta$-cells were identified by a cell capacitance $>5 \mathrm{pF}$ (Barg et al. 2000). Stimulation and recordings were controlled by PULSE software. The patch electrodes were fabricated from borosilicate glass and had a resistance of $2.5-5 \mathrm{M} \Omega$ while filled with internal recording solution. Capacitive transients and series resistance errors were minimized before recording. All experiments were carried out at room temperature $\left(22-25^{\circ} \mathrm{C}\right)$.

$\mathrm{K}_{\text {ATP }}$ currents were recorded by applying $10 \mathrm{mV}$ hyperand depolarizing voltage pulses (duration, $200 \mathrm{~ms}$; pulse interval, $2 \mathrm{~s}$ ) from a holding potential of $-70 \mathrm{mV}$ using the perforated patch whole-cell configuration. The extracellular solution consisted of (in mM) $138 \mathrm{NaCl}, 5.6 \mathrm{KCl}, 2.6 \mathrm{CaCl}_{2}$, $1.2 \mathrm{MgCl}_{2}$, and 5 HEPES (pH 7.4 with $\mathrm{NaOH}$ ) and was supplemented with glucose as indicated. The pipette solution consisted of (in mM) $76 \mathrm{~K}_{2} \mathrm{SO}_{4}, 10 \mathrm{KCl}, 10 \mathrm{NaCl}, 1 \mathrm{MgCl}_{2}, 5$ HEPES (pH 7.35 with $\mathrm{KOH}$ ), and $0.24 \mathrm{mg} / \mathrm{ml}$ of the poreforming antifungal agent amphotericin $\mathrm{B}$. The voltage clamp was considered satisfactory when the series conductance was stable and greater than $35 \mathrm{nS}$.

$\mathrm{K}_{\mathrm{v}}$ currents were recorded by a series of $10 \mathrm{mV}$ voltage steps to the potentials between -40 and $+60 \mathrm{mV}$ from the holding potential $-70 \mathrm{mV}$ using standard whole-cell patch-clamp recording mode. The extracellular solution consisted of (inmM) $135 \mathrm{NaCl}, 5.4 \mathrm{KCl}, 1 \mathrm{CaCl}_{2}$, $1.2 \mathrm{MgCl}_{2}, 10$ HEPES, and 3 glucose (pH 7.4 with $\mathrm{NaOH}$ ). The pipette solution consisted of (in $\mathrm{mM}$ ) $140 \mathrm{KCl}$, $1 \mathrm{CaCl}_{2}, 1 \mathrm{MgCl}_{2}, 10$ HEPES, 10 EGTA, and $3 \mathrm{MgATP}(\mathrm{pH} 7.3$ with $\mathrm{KOH})$.

\section{$\left[\mathrm{Ca}^{2+}\right]_{\mathrm{i}}$ recording in single islet $\beta$-cells}

$\left[\mathrm{Ca}^{2+}\right]_{\mathrm{i}}$ was measured by placing the coverslip on the stage of IX71 inverted microscope (Olympus) (Deng et al. 2014). The single islet cells were loaded with $4 \mu \mathrm{M}$ Fura 2-AM (Sigma) for $30 \mathrm{~min}$ at $37^{\circ} \mathrm{C}$ in $\mathrm{KRBB}$ containing $3 \mathrm{mM}$ glucose, then they were washed with KRBB, and stimulated with $20 \mathrm{mM}$ glucose. The single cells were illuminated by excitation at $340 \mathrm{~nm}$ (F340) and $380 \mathrm{~nm}$ (F380) using a monochromator (Till Photonics, Munich, Germany), and the emission signals were detected at $510 \mathrm{~nm}$ using an image-intensifying CCD camera (SensiCam, PCO, Kelheim, Germany). The images were

Published by Bioscientifica Ltd. 
collected at $10 \mathrm{~s}$ intervals. The $\left[\mathrm{Ca}^{2+}\right]_{\mathrm{i}}$ was expressed as the ratio of $\mathrm{F} 340 / \mathrm{F} 380(\mathrm{AU})$. The $\left[\mathrm{Ca}^{2+}\right]_{\mathrm{i}}$ peak height upon stimulation was calculated as the ratio of difference between the highest $\left[\mathrm{Ca}^{2+}\right]_{i}$ value and the baseline. The time to the peak $\left[\mathrm{Ca}^{2+}\right]_{\mathrm{i}}\left(\mathrm{T}_{\text {peak }}\right)$ was defined as a period from the point when the stimulation was applied to the point when the highest $\left[\mathrm{Ca}^{2+}\right]_{i}$ value was obtained. The maximal rate of $\mathrm{Ca}^{2+}$ rise was defined as the max velocity increase in the $\left[\mathrm{Ca}^{2+}\right]_{\mathrm{i}}$ curves (max.d $\left[\mathrm{Ca}^{2+}\right]_{\mathrm{i}} / \mathrm{dt}$ ). Calcium channel blockers, including ryanodine and 2-APB, and the vacuolar $\mathrm{H}^{+}$-ATPase inhibitor Baf-A1 were purchased from Gene Operation (Ann Arbor, MI, USA). NAADP was obtained from Sigma. Calcium-free KRBB was prepared by omitting $\mathrm{CaCl}_{2}$ from its composition. All the drugs were applied through a superfusion system.

\section{Measuring the pH in ISGs and fibroblast lysosomes}

The islet $\beta$-cells were stained with $2 \mu \mathrm{M}$ LysoSensor Green DND-189 (Molecular Probes) in $1 \mathrm{ml}$ KRBB for $30 \mathrm{~min}$ at $37^{\circ} \mathrm{C}$. Green fluorescence that accumulated in acidic organelles was imaged by Leica 710 confocal microscopy

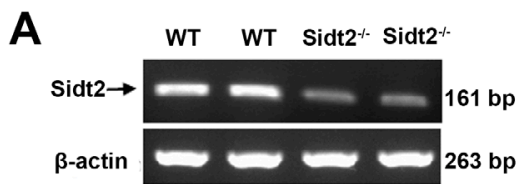

(excitation $443 \mathrm{~nm}$, emission $505 \mathrm{~nm}$ ). The fluorescence intensity was also represented as AU.

Primary cultured fibroblasts isolated from mouse tail tip were loaded with the same $\mathrm{pH}$ indicator to measure the $\mathrm{pH}$ of lysosomes. The signals were observed by Leica 710 confocal microscopy and were detected using a FACS Calibur flow cytometer (BD Biosciences, San Jose, CA, USA). Data were analyzed using FloJo version 7.6.1 (Treestar, Ashland, OR, USA).

\section{Statistical analysis}

Results are expressed as means \pm s.D. An independent-samples $t$ test was used to evaluate differences between groups. Differences were statistically significant when $P \leq 0.05$.

\section{Results}

\section{Expression and localization of SIDT2 in pancreatic $\beta$-cells}

SIDT2 expression was observed in WT islets using pair 1, and RNA expression was reduced by $70 \%$ in Sidt2-/-
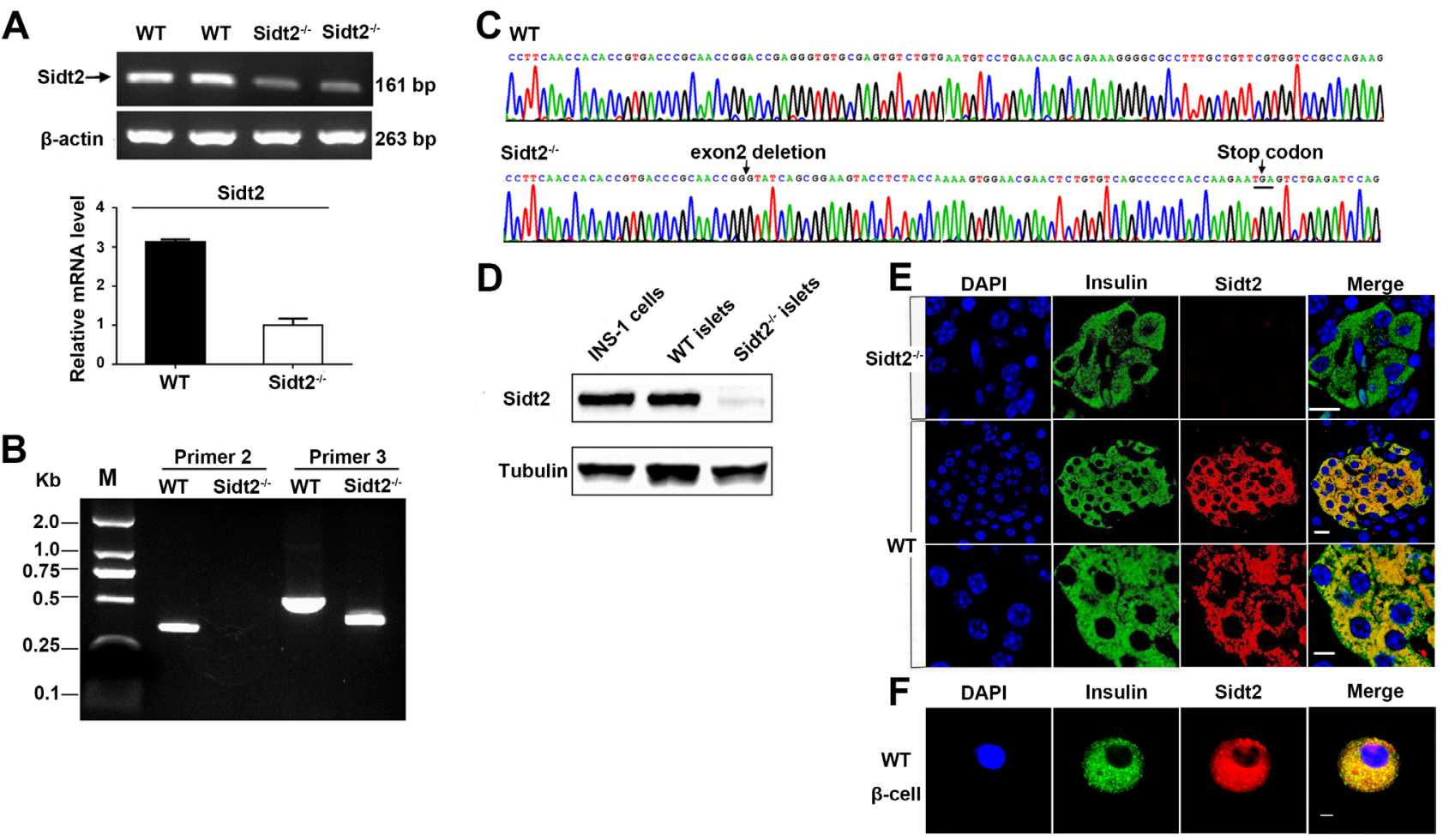

\section{Figure 1}

Analysis of SIDT2 RNA and protein expression in mouse islets. (A) qPCR analysis of Sidt2 expression. (B) RT-PCR products amplified using primer pairs 2 and 3. (C) Sequencing of the amplicon obtained with primer pair 3. (D) Western blotting of SIDT2 expression in INS-1 cells and islets. (E) Immunostaining of SIDT2 and insulin in mouse pancreatic islets (scale bars $=10,10$, and $5 \mu \mathrm{m}$ in the upper, middle, and lower panels, respectively).

(F) Immunofluorescence images of SIDT2 and insulin in a $\beta$-cell from WT mouse (scale bar $=5 \mu \mathrm{m}$ ).

$\begin{array}{lr}\text { http://jme.endocrinology-journals.org } & \text { (C) } 2016 \text { Society for Endocrinology } \\ \text { DOI:10.1530/JME-15-0227 } & \text { Printed in Great Britain }\end{array}$

Published by Bioscientifica Ltd 
islets (Fig. 1A). The Sidt2 gene-specific product obtained using pair 2 was amplified from the WT islets (Fig. 1B, lane 2), but not from Sidt2-/- islets (Fig. 1B, lane 3). The amplicon from Sidt2-/- islets using pair 3 (Fig. 1B, lane 5) was shorter than that obtained from WT islets (Fig. 1B, lane 4, WT, 535 bp; Sidt2-/-, 413 bp). Direct sequencing of the primer pair 3 amplicon confirmed the deletion of exon 2 in the Sidt2-l- islets, which was presumed to cause a premature stop codon at amino acid 83 of SIDT2 protein (Fig. 1C). Western blotting analysis revealed that SIDT2 was expressed endogenously in INS-1 cells and WT islets, whereas its expression was almost completely lost in Sidt2-/- islets (Fig. 1B). The SIDT2 signals colocalized with the insulin granules of $\beta$-cells in WT islets (Fig. 1E), as well as in single $\beta$-cells (Fig. 1F). The calculated Pearson's value for SIDT2 with insulin was 0.86 in isolated primary $\beta$-cells.

\section{Normal NAD(P)H responses to glucose in Sidt2-/- $\beta$-cells}

To assess whether SIDT2 deficiency affected glucose metabolism in $\beta$-cells, the $\mathrm{NAD}(\mathrm{P}) \mathrm{H}$ autofluorescence response to $20 \mathrm{mM}$ glucose was measured. The patterns of $\mathrm{NAD}(\mathrm{P}) \mathrm{H}$ responses to $20 \mathrm{mM}$ glucose in WT and Sidt2 $^{-/} \beta$-cells were similar (Fig. 2A). Moreover, the autofluorescence levels under $3 \mathrm{mM}$ or $20 \mathrm{mM}$ glucose were comparable between these two groups $(n=10$ islets for each group, $P>0.05$, Fig. $2 \mathrm{~B})$. NAD(P)H increase to $20 \mathrm{mM}$ glucose in Sidt2-- $\beta$-cells was not different from WT $(50.1 \pm 7.6 \mathrm{AU}$ vs $49.8 \pm 6.3 \mathrm{AU}$, WT vs Sidt2-l-, $P>0.05$, cells from 6 mice per group).

In addition, an enzymatic recycling method was used to measure the changes in NADPH in islet extracts. In WT islets, NADPH levels rose by $59 \pm 9.3 \%$ after the addition of $20 \mathrm{mM}$ glucose. Similarly, a $62 \pm 13.6 \%$ increase was observed in Sidt2 ${ }^{-/-}$mouse islets (WT vs Sidt2 ${ }^{-/}, P>0.05$, $n=300$ islets from 6 mice per group, Fig $2 \mathrm{C}$ and Fig. 2D).
These data indicate that mitochondrial glycolytic function was normal in Sidt2-/- mouse islets.

\section{Normal $\mathrm{K}_{\text {ATP }}$ and $\mathrm{K}_{\mathrm{v}}$ currents in single $\beta$-cells from Sidt2-I- mice}

The $\mathrm{K}_{\text {ATP }}$ current amplitudes were stable in $3 \mathrm{mM}$ glucose, which were inhibited markedly by $20 \mathrm{mM}$ glucose in both groups (Fig. 3A and Fig. 3B). The maximum steady-state outward currents were reduced by $65.1 \pm 4.13 \%$ in WT and $59.3 \pm 7.9 \%$ in Sidt $2^{-/-} \beta$-cells on perfusion with $20 \mathrm{mM}$ glucose $(P>0.05, n=15$ cells $)$.

$\mathrm{K}_{\mathrm{v}}$ channels in pancreatic $\beta$-cells negatively regulate $\mathrm{Ca}^{2+}$ entry and insulin secretion (Su et al. 2001). The outward voltage-dependent $\mathrm{K}^{+}$currents in Sidt2-/- $\beta$-cells were similar to those in WT $\beta$-cells, and could be antagonized by $20 \mathrm{mM}$ glucose (Figs 3C and Fig. 3E). The peak outward $\mathrm{K}_{\mathrm{V}}$ currents were reduced from $1127.4 \pm 97.6 \mathrm{pA} /$ $\mathrm{pF}$ (3 mM glucose) to $459.2 \pm 60.6 \mathrm{pA} / \mathrm{pF}$ (20 mM glucose) in WT $\beta$-cells $(P<0.01, n=20$ cells), and from $1159.7 \pm 95.8$ to $544.4 \pm 51.1 \mathrm{pA} / \mathrm{pF}$ in Sidt2-- $\beta$-cells $(P<0.01$, $n=20$ cells). The reduction in $\mathrm{K}^{+}$current by $20 \mathrm{mM}$ glucose was statistically significant in both groups when the membrane potential was clamped at $0 \mathrm{mV}(n=20$ cells, Figs 3D and Figs 3F).

\section{Attenuated and delayed glucose-stimulated $\mathrm{Ca}^{2+}$ response of Sidt2-I- $\beta$-cells}

Upon stimulation with $20 \mathrm{mM}$ glucose, the $\left[\mathrm{Ca}^{2+}\right]_{\mathrm{i}}$ in WT $\beta$-cells increased rapidly to plateau levels. In contrast, the $\left[\mathrm{Ca}^{2+}\right]_{\mathrm{i}}$ rise was impaired in Sidt2-/- $\beta$-cells (Fig. 4A). The peak height of $\left[\mathrm{Ca}^{2+}\right]_{\mathrm{i}}$ in Sidt2-/- $\beta$-cells was decreased by $45.3 \%$ compared with WT $(92.9 \pm 9.5$ AU vs $169.8 \pm 16.4$ AU, $P<0.01, n=20$ cells, Fig. $4 \mathrm{~B})$. Moreover, The time to the peak of $[\mathrm{Ca} 2+]_{\mathrm{i}}\left(\mathrm{T}_{\text {peak }}\right)$ was longer in Sidt2-/- $\beta$-cells compared with WT $(4.8 \pm 0.9 \mathrm{~min}$ vs $1.1 \pm 0.25 \mathrm{~min}$,
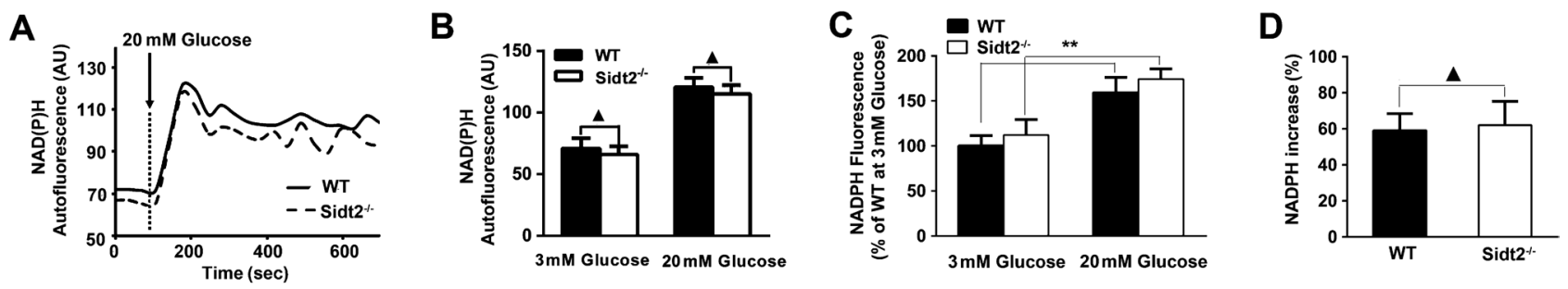

\section{Figure 2}

Glucose-induced NAD(P)H changes in Sidt2-l- $\beta$-cells. (A) The representative curves for NAD(P)H autofluorescence. (B) Quantification of NAD(P)H fluorescence ( $\beta$-cells from 6 mice per group). (C) NADPH responses to $20 \mathrm{mM}$ glucose compared with the basal levels at $3 \mathrm{mM}$ glucose with the enzymatic method ( $n=300$ islets from 6 mice per group). (D) Quantification of the NADPH responses to $20 \mathrm{mM}$ glucose compared with the basal levels at $3 \mathrm{mM}$ glucose ( $n=300$ islets from 6 mice per group). $\Delta P>0.05, * * P<0.01$. 
A

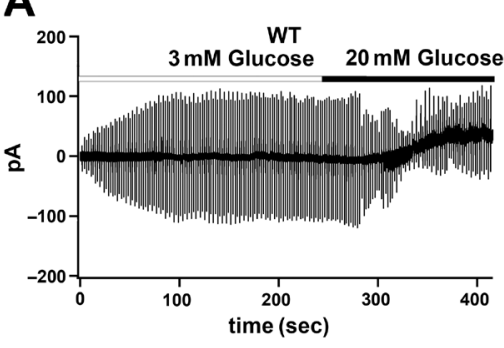

C
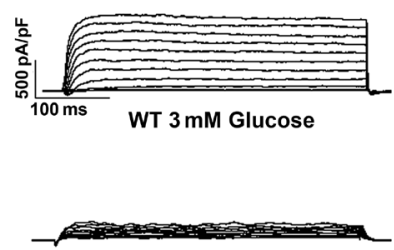

WT $20 \mathrm{mM}$ Glucose

$\mathbf{E}$
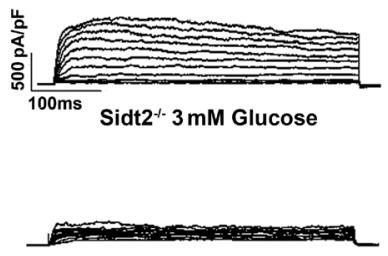

Sidt2 ${ }^{-*} 20 \mathrm{mM}$ Glucose
B

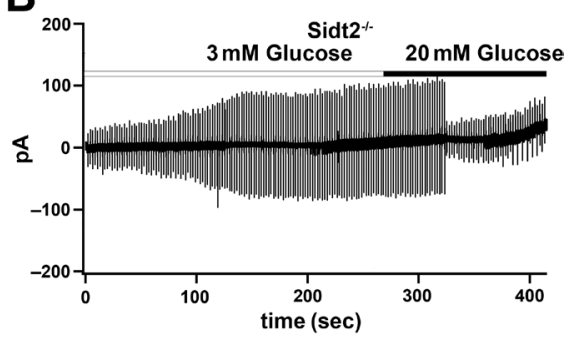

D

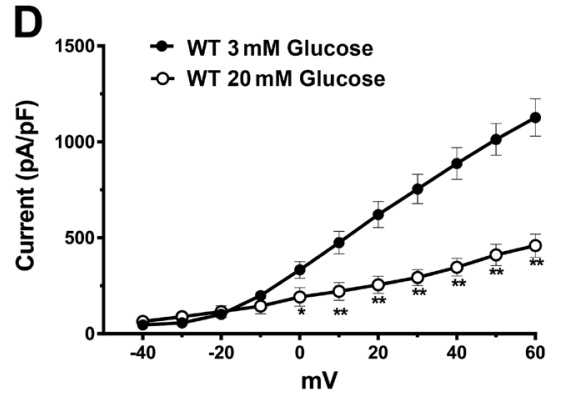

$\mathbf{F}$

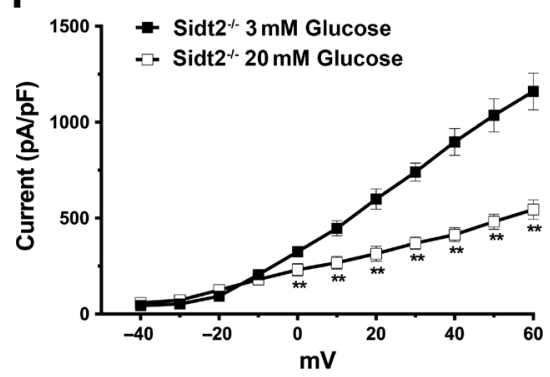

Figure 3

Single $\beta$-cell $\mathrm{K}_{\text {ATP }}$ and $\mathrm{K}_{\mathrm{V}}$ currents induced by $20 \mathrm{mM}$ glucose. ( $A$ and $B$ ) Representative recordings of whole-cell $\mathrm{K}_{\text {ATP }}$ currents. Representative traces of $\mathrm{K}_{\mathrm{v}}$ currents in (C) (WT) and (E) (Sidt2-/-). The currentvoltage relationship curves for the peak currents are plotted for WT and Sidt2--- in (D) and (F), respectively ( $n=20$ cells for each group). ${ }^{*} P<0.05, * * P<0.01$.
$P<0.01, n=20$ cells), and the maximal rate of $\left[\mathrm{Ca}^{2+}\right]_{\mathrm{i}}$ rise in Sidt2-l- $\beta$-cells was smaller than WT $(97.6 \pm 11.7$ $\mathrm{AU} / \mathrm{min}$ vs $293.1 \pm 8.6 \mathrm{AU} / \mathrm{min}, \mathrm{P}<0.01, n=20$ cells).

$\mathrm{Ca}^{2+}$ response to $50 \mathrm{mM} \mathrm{KCl}$ was also impaired in cultured $\beta$-cells from the Sidt2-l- mice (Fig. 4C). The $\mathrm{Ca}^{2+}$ peak height was $640.6 \pm 10.9$ AU vs $299.1 \pm 14.6$ AU in WT vs Sidt2-/- $\beta$-cells, respectively $(P<0.01$, $n=20$ cells).

Next we investigated where was the exact defective position of calcium signaling in Sidt2-/- $\beta$-cells on glucose stimulation. As shown in Fig. 4D, $\left[\mathrm{Ca}^{2+}\right]_{\mathrm{i}}$ increased slowly to a low level in $\mathrm{Ca}^{2+}$-free buffer (peak height, 53.7 \pm 16.5 AU, $n=10$ ) upon stimulation of $20 \mathrm{mM}$ glucose in WT $\beta$-cells. However, the rise in $\left[\mathrm{Ca}^{2+}\right]_{\mathrm{i}}$ was very low in Sidt2-l- $\beta$-cells (peak height, $3.6 \pm 1.8 \mathrm{AU}, n=10$ ) and was nearly abolished (WT vs Sidt2-/-, $P<0.01$ ), suggesting that the defect in $\left[\mathrm{Ca}^{2+}\right]_{\mathrm{i}}$ increase in Sidt2-/- $\beta$-cells was caused by reduced $\mathrm{Ca}^{2+}$ mobilization from intracellular calcium stores.

We then treated the $\beta$-cells with inhibitors of intracellular $\mathrm{Ca}^{2+}$ channels. Both $100 \mu \mathrm{M}$ ryanodine (an inhibitor of ER ryanodine receptors (RyRs)) and 50 $\mathrm{MM}$ 2-APB (an inhibitor of ER inositol trisphosphate receptors (IP3Rs)) dramatically reduced the glucose-stimulated $\mathrm{Ca}^{2+}$ response in WT and Sidt2-/- $\beta$-cells (Fig. 4E and Fig. 4F). There were no differences in the extent of $\left[\mathrm{Ca}^{2+}\right]_{\mathrm{i}}$ reduction by the ER blockers in both groups (ryanodine, $54.9 \pm 7.6 \%$ vs $49.3 \pm 5.2 \%, P>0.05 ; 2-\mathrm{APB}$, $53.8 \pm 6.3 \%$ vs $47.5 \pm 5.4 \%, P>0.05, n=20$, WT vs Sidt2-/-, Fig. 4G). These data indicate that there was no defect in $\mathrm{Ca}^{2+}$ trafficking from ER stores via RyRs or IP3R during glucose-induced CICR in Sidt2-l- $\beta$-cells. Therefore, the release of $\mathrm{Ca}^{2+}$ from intracellular stores other than the ER might be impaired in Sidt2-/- $\beta$-cells.

Treatment of cells with $3 \mu \mathrm{M}$ Baf-A1, an inhibitor of vacuolar $\mathrm{H}^{+}$-ATPase, induced a transient increase in $\left[\mathrm{Ca}^{2+}\right]_{\mathrm{i}}$ in both groups (peak height, 74.1 $\pm 2.1 \mathrm{AU}$ in WT and $71 \pm 8.3 \mathrm{AU}$ in Sidt2-/-, P>0.05, $n=15$, Figs $4 \mathrm{H}$ and Fig. 4I). Subsequent stimulation with $20 \mathrm{mM}$ glucose induced a similar $\left[\mathrm{Ca}^{2+}\right]_{\mathrm{i}}$ increase in both groups (peak height, 94.8 \pm 8.5 AU vs 87.7 \pm 7.2 AU, WT vs Sidt2-/-, $P>0.05, n=15$ ) (Fig. $4 \mathrm{H}$ and Fig. 4I). When Baf-A1

Published by Bioscientifica Ltd 
A

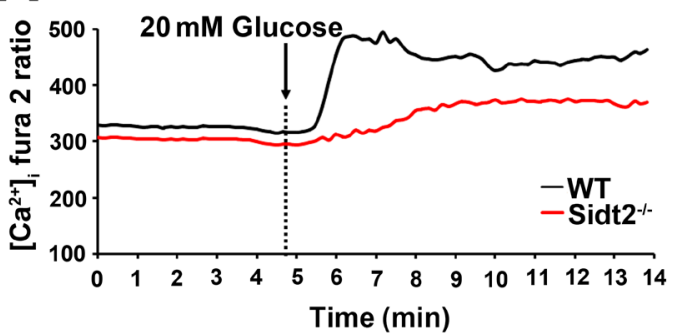

C

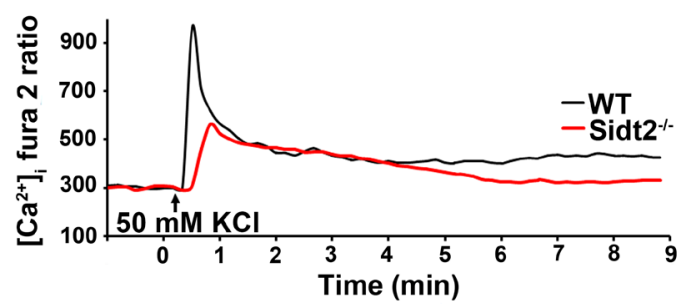

E

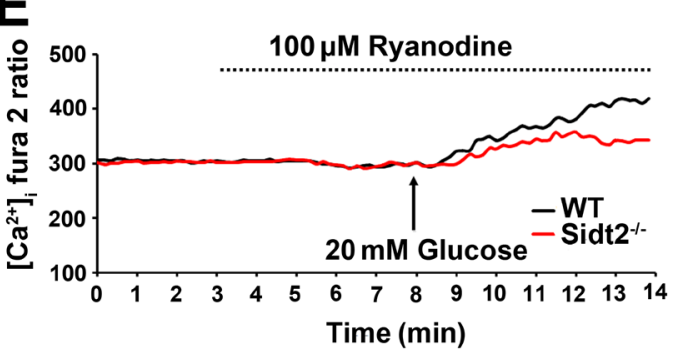

G

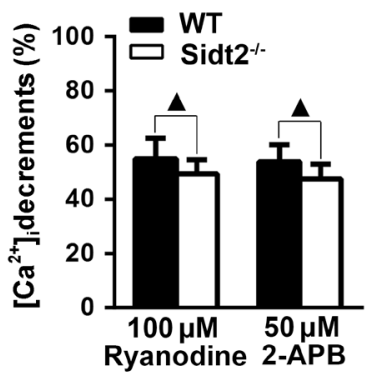

H

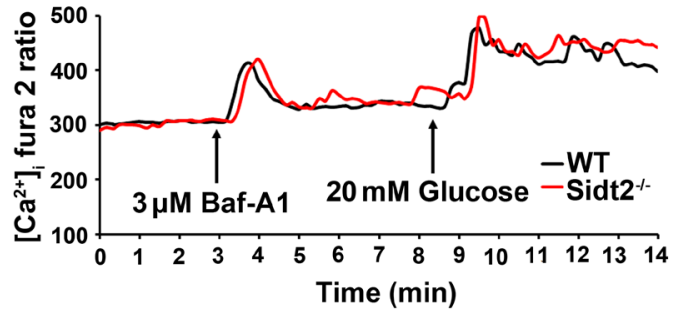

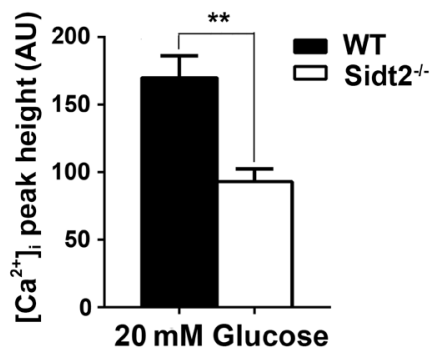

D

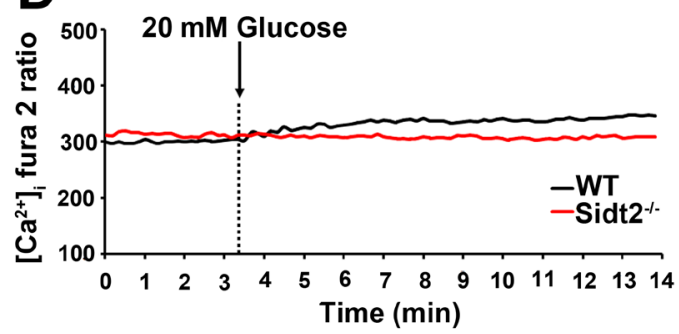

$\mathbf{F}$

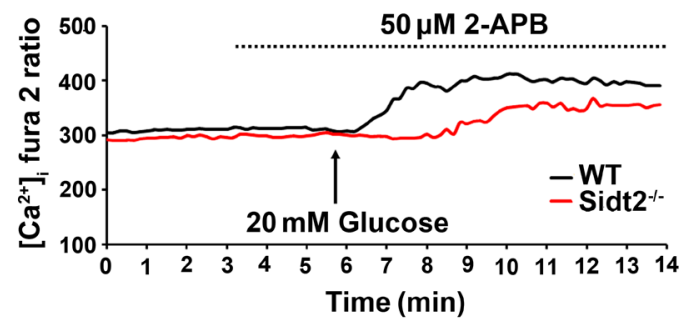

Figure 4

$\left[\mathrm{Ca}^{2+}\right]_{\mathrm{i}}$ in $\beta$-cells from Sidt2-l- mice. (A) $\left[\mathrm{Ca}^{2+}\right]_{i}$ responses of $\beta$-cells to $20 \mathrm{mM}$ glucose. (B) Quantification of $\left[\mathrm{Ca}{ }^{2+}\right]_{i}$ peak height, $n=20$ cells for each group. (C) $\left[\mathrm{Ca}^{2+}\right]_{i}$ response of $\beta$-cells to $50 \mathrm{mM} \mathrm{KCl}$. (D) $\left[\mathrm{Ca}^{2+}\right]_{i}$ responses in the absence of extracellular $\mathrm{Ca}^{2+}$. (E) $\left[\mathrm{Ca}{ }^{2+}\right]_{i}$ of $\beta$-cells pre-incubated with $100 \mu \mathrm{M}$ ryanodine. (F) $\left[\mathrm{Ca}^{2+}\right]_{i}$ of $\beta$-cells pre-incubated with $50 \mu \mathrm{M} 2-\mathrm{APB}$. (G) Quantification of $\beta$-cell $\left[\mathrm{Ca}^{2+}\right]_{i}$ decrements pre-incubated with ryanodine or $2-\mathrm{APB}, n=20$ cells. $(\mathrm{H})\left[\mathrm{Ca}^{2+}\right]_{i}$ in $\beta$-cells pre-incubated with $3 \mu \mathrm{M}$ Baf-A1 and then stimulated with $20 \mathrm{mM}$ glucose. (I) Summary of Baf-A1 effect on $\mathrm{Ca}^{2+}$ release from acidic compartments and $\left[\mathrm{Ca}^{2+}\right]_{\mathrm{i}}$ increase evoked by $20 \mathrm{mM}$ glucose, $n=15$ cells. $\mathbf{\Delta} P>0.05$. $* * P<0.01$.

A full colour version of this figure is available at http://dx.doi.org/10.1530/JME-15-0227.

depleted the calcium stores in the acidic compartments, the glucose-induced $\mathrm{Ca}^{2+}$ release from the ER and other stores was comparable between Sidt2-/- and WT $\beta$-cells. This suggests that the attenuated $\left[\mathrm{Ca}^{2+}\right]_{\mathrm{i}}$ increase in Sidt2-/- $\beta$-cells was due to impaired $\mathrm{Ca}^{2+}$ release from acidic stores.

\section{The pH of ISGs and lysosomes}

The intracellular acidic organelles of $\beta$-cell, including ISGs and lysosomes, contain high levels of calcium, and their calcium contents are affected by $\mathrm{pH}$ (Christensen et al. 2002, Suckale and Solimena 2010). In $3 \mathrm{mM}$ glucose, the granular $\mathrm{pH}$-dependent fluorescence of

Published by Bioscientifica Ltd. 

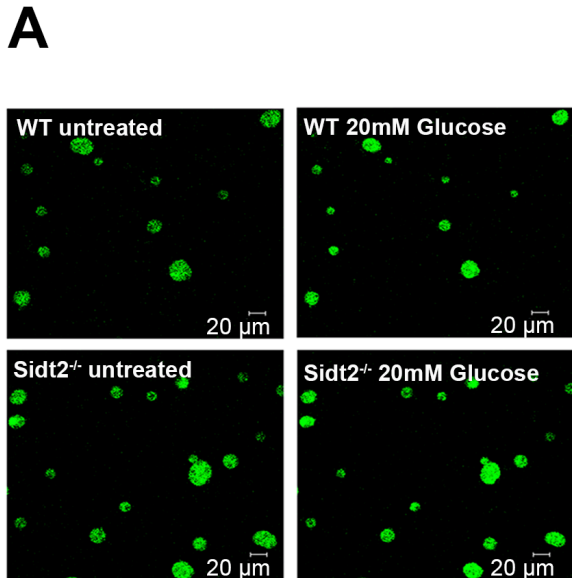

B
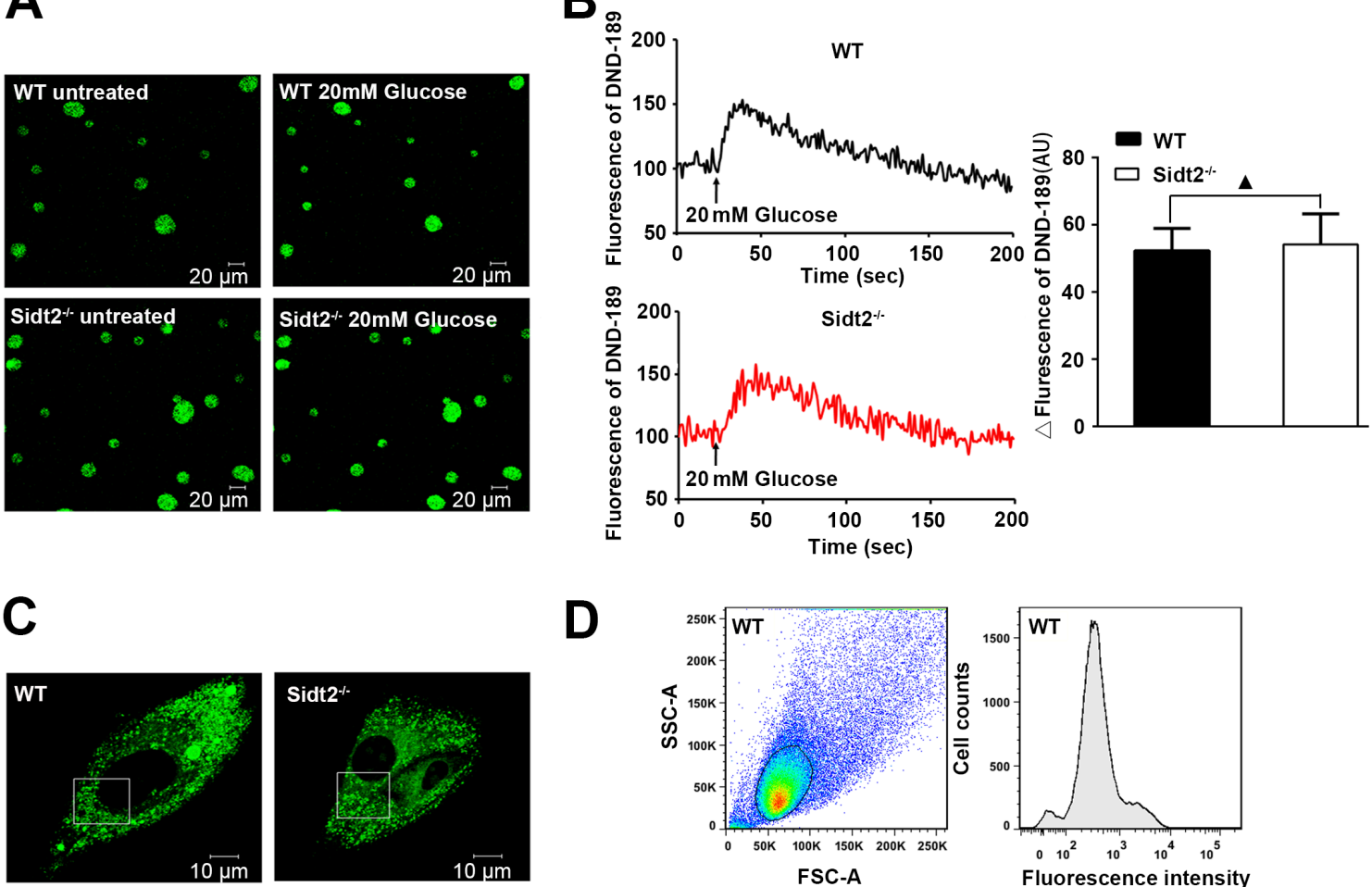

D
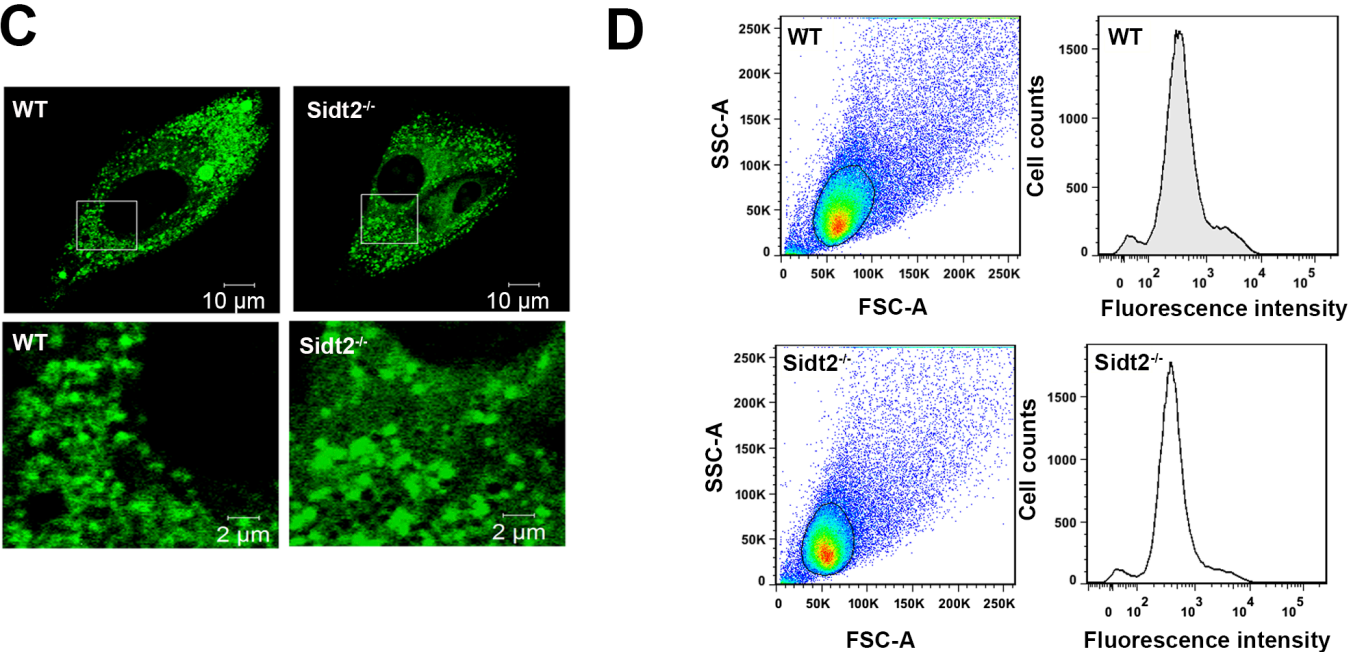

\section{Figure 5}

Measuring the $\mathrm{pH}$ in ISGs and lysosomes. (A) Live cell fluorescent images of $\mathrm{pH}$ using LysoSensor DND-189 in $\beta$-cells from Sidt2-l- and WT mice. (B) The representative curves of LysoSensor-189 signals in $\beta$-cells from Sidt2-- and WT mice and qualification of fluorescence intensity ( $n=20$ cells for each group). (C) Live cell fluorescent images of the lysosomal pH using LysoSensor DND-189 in fibroblasts from Sidt2--- and WT mouse. (D) Flow cytometric analysis of the fluorescence intensity of LysoSensor DND-189 in fibroblasts, $\Delta P>0.05$. A full colour version of this figure is available at http://dx.doi.org/10.1530/JME-15-0227.

$\beta$-cells was stable for $3 \mathrm{~min}$. The mean fluorescence intensity of WT and Sidt2-/- ISGs was $103.85 \pm 15.75$ $\mathrm{AU}$ and $100.67 \pm 13.43 \mathrm{AU}$, respectively $(n=20$ cells, $P>0.05)$. Stimulation with $20 \mathrm{mM}$ glucose caused a rapid and monophasic increase of fluorescence intensity in both WT and Sidt2 ${ }^{-/-} \beta$-cells $(52.2 \pm 6.7 \mathrm{AU}$ vs $54.2 \pm 9.1$ $\mathrm{AU}$, respectively, $P>0.05, n=20$, Figs $5 \mathrm{~A}$ and Figs $5 \mathrm{~B}$ ). These data indicate that SIDT2 deficiency had no effect on the acidification of ISGs.

Similarly, no difference was obtained in the lysosomal $\mathrm{pH}$ of Sidt2-/- fibroblasts compared with WT, which was observed by confocal microscopy (Fig. 5C) and assessed by flow cytometer $(785 \pm 72.1 \mathrm{AU}$ vs $798 \pm 31.8 \mathrm{AU}$, WT vs Sidt2--, $P>0.05$, Fig. 5D).

\section{Efficacy of NAADP treatment in Sidt2-/- $\beta$-cells}

It was reported that NAADP-induced calcium signals were not observed in extracellular calcium-free conditions (Kim et al. 2008), which is similar to our observation that the rise in $\left[\mathrm{Ca}^{2+}\right]_{\mathrm{i}}$ in response to glucose was nearly abolished in Sidt2-l- $\beta$-cells without extracellular calcium. Therefore, we assessed the effect of NAADP on Sidt $2^{-/-} \beta$-cells. The peak height of $\left[\mathrm{Ca}^{2+}\right]_{\mathrm{i}}$ in Sidt2 $2^{-/-} \beta$-cells in the presence of $50 \mathrm{nM}$ NAADP was comparable with WT $\beta$-cells without NAADP to the stimulus of $20 \mathrm{mM}$ glucose $(156.9 \pm 12.1$ $\mathrm{AU}$ vs $169.8 \pm 16.4 \mathrm{AU}$, Sidt2 $^{-/}$vs WT, $n=10$ cells, $P>0.05)$; the respective $\mathrm{T}_{\text {peak }}$ was also comparable (1.0 $\pm 0.3 \mathrm{~min}$ vs $1.1 \pm 0.3 \mathrm{~min}, n=10$ cells, $P>0.05)$. Thus,

Published by Bioscientifica Ltd 
A

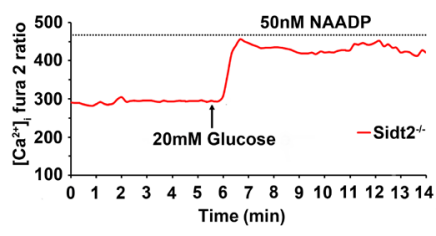

B

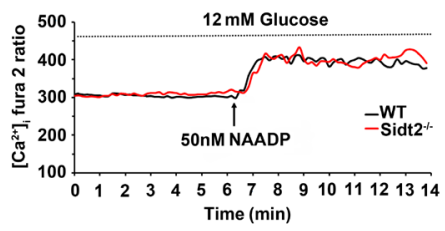

C

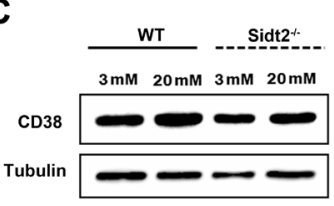

D

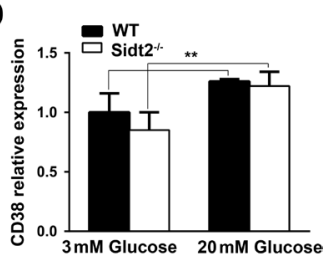

Figure 6

Efficacy of NAADP treatment in Sidt2-l- $\beta$-cells and CD38 expression. (A) Representative trace of [Ca2+ $]_{\mathrm{i}}$ in Sidt2-l- $\beta$-cells upon stimulation with 20 mM glucose in the presence of $50 \mathrm{nM}$ NAADP. (B) $\left[\mathrm{Ca}^{2+}\right]_{i}$ responses to $50 \mathrm{nM}$ NAADP in the presence of $12 \mathrm{mM}$ glucose. (C) Western blotting of glucoseinduced CD38 expression in Sidt2-/- and WT islets. (D) Qualification of glucose-induced CD38 expression. $* * P<0.01$. A full colour version of this figure is available at http://dx.doi.org/10.1530/JME-15-0227.

bath-mediated application of NAADP rescued $\left[\mathrm{Ca}^{2+}\right]_{\mathrm{i}}$ response of Sidt2-l- $\beta$-cells to glucose (Fig. 6A).

In the presence of $12 \mathrm{mM}$ glucose, stimulation with $50 \mathrm{nM}$ NAADP induced a comparable $\left[\mathrm{Ca}^{2+}\right]_{\mathrm{i}}$ response in both the WT and Sidt2-/- groups (peak height, $112.9 \pm 6.5 \mathrm{AU}$ vs $111.5 \pm 8.6 \mathrm{AU}$, WT vs Sidt2 ${ }^{--}, P>0.05, n=10$ ) (Fig. $6 \mathrm{~B}$ ).

\section{CD38 expression in WT and Sidt2-/- islets}

Since the above data implied reduced $\left[\mathrm{Ca}^{2+}\right]_{i}$ increase in Sidt2-l- $\beta$-cells was related with NAADP signaling, we investigated whether NAADP generation was deficient in Sidt2-/- $\beta$-cells. CD38 is located in endosomes, secretory granules, and lysosomes. It is an ADP-ribosyl cyclase responsible for endogenous NAADP generation in $\beta$-cells (Kim et al. 2008). As shown in Figs 6C and Figs 6D, glucoseinduced CD38 expression increased by $27 \pm 9.1 \%$ in WT and $32.3 \pm 10.8 \%$ in Sidt2 ${ }^{-/-} \beta$-cells $(P>0.05)$, suggesting that NAADP production was normal in Sidt2-/- $\beta$-cells upon glucose stimulation.

\section{Discussion}

Previous proteomic studies identified some lysosomalassociated membrane proteins such as LAMP2, Syntaxin7, VAMP8, and Cathepsins L1, D, and F are expressed in ISGs (Brunner et al. 2007, Schvartz et al. 2012). The current study demonstrated that SIDT2, which was identified previously in mouse/rat liver lysosomes, was also endogenously expressed in mouse islet $\beta$-cells, and that it co-localized with ISGs.

The $\beta$-cells in rodent models have been estimated to contain 10,000 ISGs, which corresponds to $12-20 \%$ of the total cell volume (PM 1973). ISGs contain the highest calcium concentrations among all intracellular compartments. Compared with the total calcium concentrations in the cytoplasm of $\beta$-cells, ISGs contain two-fold higher levels of calcium (Norlund et al. 1987). Only a small number of lysosomes are present in the islet $\beta$-cells (Barg et al. $2001)$, and the lysosomal volume of mouse islet $\beta$-cells was only 3-5\% of that of ISGs (Schnell Landstrom et al. 1991). Therefore, the impaired $\mathrm{Ca}^{2+}$ response in Sidt2-/$\beta$-cells likely results mainly from defects in calcium release from the ISG stores.

NAADP is the second messenger that mobilizes $\mathrm{Ca}^{2+}$ from acidic organelles. NAADP-mediated $\mathrm{Ca}^{2+}$ release plays a key role in triggering glucose-induced $\mathrm{Ca}^{2}+$ signaling events (Arredouani et al. 2010). However, the identity of the NAADP receptor channel in acidic organelles remains elusive. Recent data have indicated that neither TPCs nor the transient receptor potential channel mucolipin 1 (TRP-ML1) is the NAADP receptor (Lin-Moshier et al. 2012, Zhang et al. 2011). Bath-application of extracellular NAADP has been shown to induce intracellular calcium increase, at least partially through increase in intracellular NAADP (Djerada and Millart 2013, Singaravelu and Deitmer 2006). In the current study, the bath-application of NAADP corrected the impaired $\left[\mathrm{Ca}^{2+}\right]_{\mathrm{i}}$ increase in Sidt $2-1-\beta$-cells, suggesting that SIDT2 exerts its function on the upstream of NAADP-medicated calcium release from acidic store. In other words, SIDT2 may regulate NAADP production in ISGs or function as a modulator to the NAADP- regulated $\mathrm{Ca}^{2+}$ channel.

In this study, the equal glucose-induced CD38 expression in WT and Sidt2-/- islets indicates that the generation of NAADP was not different between the two groups. Based on the localization of SIDT2 on the membranes of intracellular acidic compartments and its nine transmembrane domain structures (Jialin et al. 2010), and taken together the results of this study, we propose that SIDT2 may be required to assembly with TPCs to form a functional $\mathrm{Ca}^{2+}$-release channel, or function as a modulator to the NAADP- regulated $\mathrm{Ca}^{2+}$ channel in ISGs.

In conclusion, this study demonstrated that SIDT2 was expressed in mouse pancreatic $\beta$-cells, and co-localized

Published by Bioscientifica Ltd. 
predominantly with ISGs. It plays an important role in regulating NAADP-mediated ISG calcium release and glucose-induced insulin secretion.

\section{Declaration of interest}

The authors declare that there is no conflict of interest that could be perceived as prejudicing the impartiality of the research reported.

\section{Funding}

This project is supported by NSFC $(81270936,81570516)$, Shanghai RisingStar Program (12QH1401800).

\section{Author contribution statement}

All authors contributed to the study conception and design. G C and $R \mathrm{Y}$ researched the data. $\mathrm{Y} C$ and $\mathrm{A} N$ helped the electrophysiological recording of cells. $\mathrm{G} \mathrm{C}$ and $\mathrm{H} \mathrm{Z}$ wrote the paper. $\mathrm{H} \mathrm{Z}$ and X $\mathrm{G}$ designed the project.

\section{Acknowledgments}

The authors thank Dr Bao-liang Song for advice and assistance.

\section{References}

Arredouani A, Evans AM, Ma J, Parrington J, Zhu MX \& Galione A 2010 An emerging role for NAADP-mediated $\mathrm{Ca} 2+$ signaling in the pancreatic beta-cell. Islets 2 323-330. (doi:10.4161/isl.2.5.12747)

Bagshaw RD, Mahuran DJ \& Callahan JW 2005 Lysosomal membrane proteomics and biogenesis of lysosomes. Molecular Endocrinology 32 27-41. (doi:10.1385/MN:32:1:027)

Barg S, Galvanovskis J, Gopel SO, Rorsman P \& Eliasson L 2000 Tight coupling between electrical activity and exocytosis in mouse glucagon-secreting alpha-cells. Diabetes 49 1500-1510. (doi:10.2337/diabetes.49.9.1500)

Barg S, Huang P, Eliasson L, Nelson DJ, Obermuller S, Rorsman P, Thevenod F \& Renstrom E 2001 Priming of insulin granules for exocytosis by granular $\mathrm{Cl}(-)$ uptake and acidification. Journal of Cell Science 114 2145-2154.

Bratanova-Tochkova TK, Cheng H, Daniel S, Gunawardana S, Liu YJ, Mulvaney-Musa J, Schermerhorn T, Straub SG, Yajima H \& Sharp GW 2002 Triggering and augmentation mechanisms, granule pools, and biphasic insulin secretion. Diabetes 51 (Supplement1) S83-90. (doi:10.2337/diabetes.51.2007.S83)

Brunner Y, Coute Y, Iezzi M, Foti M, Fukuda M, Hochstrasser DF, Wollheim CB \& Sanchez JC 2007 Proteomics analysis of insulin secretory granules. Molecular \& Cellular Proteomics 6 1007-1017. (doi:10.1074/mcp.M600443-MCP200)

Calcraft PJ, Ruas M, Pan Z, Cheng X, Arredouani A, Hao X, Tang J, Rietdorf K, Teboul L, Chuang KT, et al. 2009 NAADP mobilizes calcium from acidic organelles through two-pore channels. Nature 459 596-600. (doi:10.1038/nature08030)

Cang C, Zhou Y, Navarro B, Seo YJ, Aranda K, Shi L, Battaglia-Hsu S, Nissim I, Clapham DE \& Ren D 2013 mTOR regulates lysosomal ATP-sensitive two-pore $\mathrm{Na}(+)$ channels to adapt to metabolic state. Cell 152 778-790. (doi:10.1016/j.cell.2013.01.023)

Chapel A, Kieffer-Jaquinod S, Sagne C, Verdon Q, Ivaldi C, Mellal M, Thirion J, Jadot M, Bruley C, Garin J, et al. 2013 An extended proteome map of the lysosomal membrane reveals novel potential transporters. Molecular \& Cellular Proteomics 12 1572-1588. (doi:10.1074/mcp.M112.021980)

Christensen KA, Myers JT \& Swanson JA 2002 pH-dependent regulation of lysosomal calcium in macrophages. Journal of Cell Science $\mathbf{1 1 5}$ 599-607.

Deng R, Nie A, Jian F, Liu Y, Tang H, Zhang J, Zhang Y, Shao L, Li F, Zhou L, et al. 2014 Acute exposure of beta-cells to troglitazone decreases insulin hypersecretion via activating AMPK. Biochimica et Biophysica Acta 1840 577-585. (doi:10.1016/j.bbagen.2013.10.021)

Djerada Z \& Millart H 2013 Intracellular NAADP increase induced by extracellular NAADP via the P2Y11-like receptor. Biochemical and Biophysical Research Communications 436 199-203. (doi:10.1016/j.bbrc.2013.04.110)

Elhassan MO, Christie J \& Duxbury MS 2012 Homo sapiens systemic RNA interference-defective- 1 transmembrane family member 1 (SIDT1) protein mediates contact-dependent small RNA transfer and microRNA-21-driven chemoresistance. Journal of Biological Chemistry 287 5267-5277. (doi:10.1074/jbc.M111.318865)

Eliasson L, Renstrom E, Ding WG, Proks P \& Rorsman P 1997 Rapid ATP-dependent priming of secretory granules precedes $\mathrm{Ca}(2+)$ induced exocytosis in mouse pancreatic B-cells. Journal of Physiology 503 (Pt 2) 399-412. (doi:10.1111/j.1469-7793.1997.399bh.x)

Galione A, Evans AM, Ma J, Parrington J, Arredouani A, Cheng X \& Zhu MX 2009 The acid test: The discovery of two-pore channels (TPCs) as NAADP-gated endolysosomal $\mathrm{Ca}(2+)$ release channels. Pflugers Archiv 458 869-876. (doi:10.1007/s00424-009-0682-y)

Gao J, Gu X, Mahuran DJ, Wang Z \& Zhang H 2013 Impaired glucose tolerance in a mouse model of sidt2 deficiency. PLoS One 8 e66139. (doi:10.1371/journal.pone.0066139)

Gylfe E, Ahmed M, Bergsten P, Dansk H, Dyachok O, Eberhardson M, Grapengiesser E, Hellman B, Lin JM, Sundsten T, et al. 2000 Signaling underlying pulsatile insulin secretion. Upsala Journal of Medical Sciences 105 35-51. (doi:10.1517/03009734000000054)

Islam MS 2010 Calcium signaling in the islets. Advances in Experimental Medicine and Biology 654 235-259. (doi:10.1007/978-90-481-3271-3 11)

Jialin G, Xuefan G \& Huiwen Z 2010 SID1 transmembrane family, member 2 (Sidt2): A novel lysosomal membrane protein. Biochemical and Biophysical Research Communications 402 588-594. (doi:10.1016/j.bbrc.2010.09.133)

Kang G, Chepurny OG, Rindler MJ, Collis L, Chepurny Z, Li WH, Harbeck M, Roe MW \& Holz GG 2005 A cAMP and Ca2 + coincidence detector in support of $\mathrm{Ca} 2+$-induced $\mathrm{Ca} 2+$ release in mouse pancreatic beta cells. Journal of Physiology 566 173-188. (doi:10.1113/jphysiol.2005.087510)

Kang G \& Holz GG 2003 Amplification of exocytosis by Ca2+-induced Ca2 + release in INS-1 pancreatic beta cells. Journal of Physiology 546 175-189. (doi:10.1113/jphysiol.2002.029959)

Kim BJ, Park KH, Yim CY, Takasawa S, Okamoto H, Im MJ \& Kim UH 2008 Generation of nicotinic acid adenine dinucleotide phosphate and cyclic ADP-ribose by glucagon-like peptide- 1 evokes Ca 2 + signal that is essential for insulin secretion in mouse pancreatic islets. Diabetes 57 868-878. (doi:10.2337/db07-0443)

Kinnear NP, Boittin FX, Thomas JM, Galione A \& Evans AM 2004 Lysosome-sarcoplasmic reticulum junctions. A trigger zone for calcium signaling by nicotinic acid adenine dinucleotide phosphate and endothelin-1. Journal of Biological Chemistry 279 54319-54326. (doi:10.1074/jbc.M406132200)

Lacy PE \& Kostianovsky M 1967 Method for the isolation of intact islets of Langerhans from the rat pancreas. Diabetes 16 35-39. (doi:10.2337/diab.16.1.35)

Lin-Moshier Y, Walseth TF, Churamani D, Davidson SM, Slama JT, Hooper R, Brailoiu E, Patel S \& Marchant JS 2012 Photoaffinity labeling of nicotinic acid adenine dinucleotide phosphate (NAADP) targets in mammalian cells. Journal of Biological Chemistry $\mathbf{2 8 7}$ 2296-2307. (doi:10.1074/jbc.M111.305813) http://jme.endocrinology-journals.org DOI:10.1530/JME-15-0227
(C) 2016 Society for Endocrinology Printed in Great Britain 
Morgan AJ \& Galione A 2014 Two-pore channels (TPCs): Current controversies. Bioessays 36 173-183. (doi:10.1002/bies.201300118)

Norlund R, Roos N \& Taljedal IB 1987 Quantitative energy dispersive $\mathrm{X}$-ray microanalysis of eight elements in pancreatic endocrine and exocrine cells after cryo-fixation. Bioscience Reports 7 859-869. (doi:10.1007/BF01119477)

Patel S, Churchill GC \& Galione A 2001 Coordination of $\mathrm{Ca} 2+$ signalling by NAADP. Trends in Biochemical Sciences 26 482-489. (doi:10.1016/S0968-0004(01)01896-5)

PM D 1973 Ultrastructural morphometry of the pancreatic B-cell. Diabetologia 9 115-119. (doi:10.1007/BF01230690)

Roderick HL, Berridge MJ \& Bootman MD 2003 Calcium-induced calcium release. Current Biology 13 R425. (doi:10.1016/S0960-9822(03)00358-0)

Ruas M, Davis LC, Chen CC, Morgan AJ, Chuang KT, Walseth TF, Grimm C, Garnham C, Powell T, Platt N, et al. 2015 Expression of $\mathrm{Ca} 2+$-permeable two-pore channels rescues NAADP signalling in TPC-deficient cells. EMBO Journal 34 1743-1758. (doi:10.15252/embj.201490009)

Schnell Landstrom AH, Andersson A \& Borg LA 1991 Lysosomes and pancreatic islet function: Adaptation of beta-cell lysosomes to various metabolic demands. Metabolism 40 399-405.

Schvartz D, Brunner Y, Coute Y, Foti M, Wollheim CB \& Sanchez JC 2012 Improved characterization of the insulin secretory granule proteomes. Journal of Proteomics 75 4620-4631. (doi:10.1016/j.jprot.2012.04.023)

Singaravelu K \& Deitmer JW 2006 Calcium mobilization by nicotinic acid adenine dinucleotide phosphate (NAADP) in rat astrocytes. Cell Calcium 39 143-153. (doi:10.1016/j. ceca.2005.10.001)
Su J, Yu H, Lenka N, Hescheler J \& Ullrich S 2001 The expression and regulation of depolarization-activated $\mathrm{K}+$ channels in the insulinsecreting cell line INS-1. Pflugers Archiv 442 49-56.

Suckale J \& Solimena M 2010 The insulin secretory granule as a signaling hub. Trends in Biochemical Sciences 21 599-609. (doi:10.1016/j.tem.2010.06.003)

Varadi A \& Rutter GA $2004 \mathrm{Ca} 2+$-induced $\mathrm{Ca} 2$ + release in pancreatic islet beta-cells: Critical evaluation of the use of endoplasmic reticulum-targeted "cameleons". Endocrinology 145 4540-4549. (doi:10.1210/en.2004-0241)

Wang X, Zhang X, Dong XP, Samie M, Li X, Cheng X, Goschka A, Shen D, Zhou Y, Harlow J, et al. 2012 TPC proteins are phosphoinositide- activated sodium-selective ion channels in endosomes and lysosomes. Cell 151 372-383. (doi:10.1016/ j.cell.2012.08.036)

Yamasaki M, Masgrau R, Morgan AJ, Churchill GC, Patel S, Ashcroft SJ \& Galione A 2004 Organelle selection determines agonist-specific Ca2 + signals in pancreatic acinar and beta cells Journal of Biological Chemistry 279 7234-7240. (doi:10.1074/jbc. M311088200)

Zhang F, Xu M, Han WQ \& Li PL 2011 Reconstitution of lysosomal NAADP-TRP-ML1 signaling pathway and its function in TRP-ML1(-/-) cells. American Journal of Physiology - Cell Physiology 301 C421-430. (doi:10.1152/ajpcell.00393.2010)

Zhang H, Fan X, Bagshaw RD, Zhang L, Mahuran DJ \& Callahan JW 2007 Lysosomal membranes from beige mice contain higher than normal levels of endoplasmic reticulum proteins. Journal of Proteome Research 6 240-249. (doi:10.1021/pr060407o)

Received in final form 20 December 2015

Accepted 6 January 2016

Accepted Preprint published online 7 January 2016 http://jme.endocrinology-journals.org DOI:10.1530/JME-15-0227
(C) 2016 Society for Endocrinology Printed in Great Britain
Published by Bioscientifica Ltd 